\title{
The Formation of the Bipolar Structure of International Finance after World War II
}

\author{
Angang Li \\ Centre for Non-Traditional Security Studies in ASEAN \\ Zhejiang Police College \\ Hangzhou, China
}

\begin{abstract}
The devastating blow brought by the Second World War not only changed the international political and economic situation, but also prompted the international community to reflect on the meaning of war, which laid the foundation for peace and development after the war and made postwar reconstruction become the primary goal of all countries. However, cooperation and development failed to not completely cross the ideological bondage and expressed in the form the integral confrontation of the ideological, that is, the confrontation between capitalism and socialism. This is also what the concept of structural differences cannot be avoided. A single country could be materially constrained in the development by the lack of production factors, but the cluster advantage brought by the group of countries could make up for this shortcoming, which resulted in a capitalist camp led by the United States and socialist camp led by the Soviet Union, and the Bretton Woods System and the Comecon become the stabilizer of peace and development of the two camps after the war.
\end{abstract}

Keywords-regional financial system; the Bipolar Structure; the Comecon; the Bretton Woods System

\section{INTRODUCTION}

In 1944, representatives from 44 countries around the world hold a meeting, which adopted the Keynesian liberal design and drafted and signed the Bretton Woods Agreement, in the Bretton Woods in New Hampshire, USA. The Bretton Woods Conference produced two main institutions: International Bank for Reconstruction and Development (IBRD) and International Monetary Fund (IMF). The former's goal is helping member states to rehabilitate the economy after the war and assisting the original colonial countries to develop domestic economy and realize industrialization. The aim of both two is to "establish an international monetary system to achieve full domestic employment and price stability, and to enable countries to achieve external balance [1] without limiting international trade."

Although the "Bretton Woods Agreement" was signed when World War II came to an end, the dawn of war already appeared. At this point, the political and economic situation of the world undergone profound changes, the general decline in Europe and the strong rise of the United States and the Soviet Union formed a huge contrast. The United States and the Soviet Union suddenly emerged. When the Europe was generally declined and the British completely lost the international financial dominance, especially United States, as a capitalist upstart, undertook, by advantages of economic, political and military, the leadership work of post-war reconstruction, intended to dominate the development of international finance, established their own dominance in the capitalist world, and made material preparations for the upcoming the struggle for hegemony.

In 1945, after the death of Roosevelt, "Brandenburg dynasty miracle" which was excepted by Hitler and Yi Pei Er sieged in Berlin did not repeated, the power vacuum caused by the collapse of the Nazi German reconstructed the power pattern of the international system. The confrontation between the two camps of fascism and the anti-fascist lost its significance for loss of material power. The foundation of the identity of the anti-fascist camp disappeared, and partnerships of the wartime alliance were dismissed. The national concept of the alliance began to divide: Britain wanted to prevent the Soviet from controlling Eastern Europe, the Soviet Union would like to expand the territory, and the United States hoped to keep the practice of Roosevelt period to maintain the cooperation of allies. However, when President Truman ended one term of office, the relations of wartime Allies ceased to exist, and the United States and the Soviet Union had confronted each other in European affairs.[2] In short, the alliance of the anti-fascist camp collapsed because of the disappearance of external competitors, which in turn affected the internal identity of the camp.

\section{THE FORMATION OF THE BRETTON WOODS SYSTEM}

The US economy outshone others in the early years after the war thriving, which is benefited from vigorously promotion of the wartime demand. After the war, the Western met a technological wave and production surge and the economy of the US had been further improved. After the war the United States swept $60 \%$ of major technological innovation of the Western countries and applied firstly $75 \%$ of its results to the domestic market.[3] However, the economic characteristics of monopoly capitalism also exacerbate the destructive effect on the productive forces, and the contradiction between the sociality of production and the privatization of capitalism is intensified, which 
significantly influenced process of economic development in the United States and made it aggravated and relatively slow.

In terms of gross national product (GDP), according to US official data, "the gross national product of the United States in 1946 reached US \$ 477.7 billion and developed to be US $\$ 1,322.7$ billion in 1977 by 30 years. The average annual growth rate from 1946 to 1977 is $3.4 \%$ and higher than the pre-war period. In terms of production of material production department, agricultural production was far behind industry. From 1946 to 1977, agriculture grew by only about $60 \%$, but industrial production increased by almost three times, which was mainly from the manufacturing sector. In the respect of technology industry, the emerging industrial department also achieved rapid development. From 1950 to 1970 , the annual output value of electronic communication equipment increased from \$ 270 million to $\$ 8.45$ billion, up to 31.3 times; The annual output of civil aircraft increased from $\$ 100$ million to $\$ 3.18$ billion; the annual output value of electronic components increased from $\$ 700$ million to $\$ 4.5$ billion, or 6.4 times. "[4]

In fact, the US industry was able to show advantages than agriculture, which lied mainly in its national strategy of the national economy militarization. Inspired by the strong demand from the military industry in wartime, the military orders in the United States still remained at a high level after the war. The military industry did not decline in the post-war period, but also showed a further development trend, and led the development of related industries. "During the 19501953 Korean War, US industrial production grew at an average annual rate of 9 percent, and during the 1964-1973 expansion of the war, the average annual growth rate reached 5.3 percent."[5]

The United States, by its strong economic strength, putted forward the famous "The Marshall Plan", which aimed to help European allies recover the economic system that was almost destroyed by World War II and prevent the infiltration and expansion of Soviet and communist forces in Europe. The Bretton Woods System the United States advocated and established and dominated had also become the regional financial system of the capitalist world. In the capitalist world, the United States controlled, by firmly controlling the IMF and IBRD voting groups, the economic development of the West and has an impact on post-war Western politic and economic development. Among them, the allocation power of IMF and IBRD voting share had become an important reference for Western financial power structure. These two institutions were nominally a broad platform for post-war cooperation, but were actually a tool for the developed capitalist countries headed by the United States. The United States occupied a central position in both institutions, and affected institutional decisions and development by voting share. Although the two institutions experienced several adjustments in the subsequent 60 years, its basic character and power distribution pattern were not changed. [6]

The United States implemented Keynesianism in the design of the IMF and IBRD, and emphasized the capitalism nature of the two institutions, which prevented the possibility of being socialist from the fundamental. In the "golden dollar" stage, the authority of the United States in the Bretton Woods System could not be shook, and the system played under the auspices of the United States a significant role for the post-war reconstruction of the capitalist. Of course, the hegemony of US was not recognized by all countries, and internal contradictions and conflicts often occurred.

\section{THE FORMATION OF THE COUNCIL FOR MUTUAL ECONOMIC ASSISTANCE}

Compared with that the United States made a lot of profits during the war in World War II and led overall in aspects of the political, economic and military after the war, the Soviet Union made a great sacrifice in World War II, but also won in the world a high reputation and prestige, especially the political and moral influence in the international political arena. When the war came to an end, the countries, which established diplomatic relations with the Soviet Union, reached 52. At the same time, the Soviet Union expanded its own territory through various means such as voluntary accession and occupation, and broke through the borders by the socialist civilization and established the socialist camp with the multinational countries, and formed a socialist system that rivaled the Western capitalist system. The Soviet Union therefore bid farewell to the history of the West isolation and block, and gradually become the political, economic and military center of the East.

The Soviet Union quickly restored the domestic economy, which was severely damaged by the war, and laid the economic foundation for its superpower. The Soviet Union successfully implemented the five-year economic recovery plan from 1946 to 1950 . "The industrial output value of the Soviet Union exceeded the pre-war level in 1948, and the industrial production level in 1950 exceeded $73 \%$ in 1940 . In 1950, iron production was 19 million tons, steel 27 million tons, coal mining capacity more than 26 million tons, crude oil 38 million tons. National income increased by $64 \%$. The recovery of agricultural production was relatively slow, and in 1950 it was only $99 \%$ of that in 1940 . "The recovery and development of the Soviet economy made him become a superpower and provides a firm material guarantee for the confrontation with the United States in the political, economic and military.

Although the Soviet Union suffered serious losses in the wartime, but its strong military strength remained after the war. At the end of the war, the number of Soviet armed forces reached 11.66 million, which was the highest in the world. During the last three years of the war, the Soviet Union produced each year an average of 40,000 aircraft, more than 30,000 tanks and more than 30,000 pieces of automatic weapons, 120,000 cannons, 450,000 machine guns, more than 300 million rifles and more than 200 million submachine guns, 100,000 mortars and hundreds of millions of shells. In addition to the production of aircraft, the Soviet Union's weapons production capacity ranked first in the world,"[7] which provided a strong backing for its implementation of foreign policy and becoming a superpower. 
The recovery and development of the Soviet economy had shifted its attention from domestic to international, and deeply felt the pressure from the United States. Stalin, the Soviet leader, thought the Marshall Plan was a serious threat to the Soviet Union and communism, and said the Marshall Plan "intervened in the internal affairs of other countries", "repeated Trumanism, exerted political pressure on by dollar" and expressed that the Soviet Union could not accept Marshall plans and encouraged the Eastern European countries to refuse to join, putted forward the famous "Molotov Plan" confrontationally (Molotov Plan), that is, "economic mutual aid committee" (hereinafter referred to as "Comecon").

That the Soviet Union launched the Molotov Plan was quite a reluctant action. On the one hand, because after five years of development, the Soviet economy restored and developed, but still could not be compared with the United States, the United States would certainly implement the economic strength of the standard in the implementation of the Marshall Plan, and the Soviet Union was not dominant in this regard. And Bretton Woods System, which implemented the Keynesian, was simply a capitalist mainstream financial platform. Even if the Soviet Union joined, it would certainly be excluded, which was unacceptable to the Soviet Union. On the other hand, in the face of the aggressive Marshall plan, the Soviet Union and the Eastern European countries urgently needed a platform to strengthen economic and trade exchanges between countries, promote the overall development of the socialist camp and resist the economic expansion from the capitalist countries.

In April 1949, the first meeting of Comecon was held in Moscow, which officially announced the establishment of Comecon. Unlike the Bretton Woods System, it is not through the vote to influence the decision-making and development of the institutions. The establishment of the communique specified that it was different from the Bretton Woods System. Comecon was the inevitable choice for the socialist camp to fight back the Marshall Plan. It protected the East from the sovereign oppression of the West and the fate of economic exploitation. In other words, the Marshall Plan's voting share mechanism was grossly violating national sovereignty and economic interests of other countries in a form of institution. This mode of sovereignty transfer was viewed as a violation of the sovereignty of the state at that time, which was unacceptable for the Soviet Union. It was clear in the notice of its establishment that the representatives of the Member States had equal rights and obligations in Comecon.

The organization structure of Comecon was, from top to bottom, the Comecon meeting, and the executive committee of Comecon and the Standing Committee. The Comecon meeting was the highest decision-making body of Comecon, which was composed of delegations of the member countries. The head of the meeting was usually held by the heads of the member countries. It was held once a year and was held in the capital of each member country in turn. The head of the holding country was the chairman of the session. The meeting was responsible for formulating the main policy of Comecon exchange, discussing the reports provided by the
Board, appointing the Secretariat and so on; the members of the Executive Committee should be elected by the Deputy Prime Minister of the Member States and responsible for the day-to-day operation during the non-session of the meeting. The Standing Committee was responsible for the development of cooperative measures among Member States, resolutions and the elaboration of multilateral cooperation agreements. [8]

The Comecon was a regional economic system established on the basis of the regional economic development model of the Soviet Union. Therefore, its system was designed with obvious color of the Soviet Union. Its organizational characteristics were highly planned and far from the market economy model. The internal trade and exchanges of the Comecon was mainly expressed by the radial structure focus on the Soviet Union.[9] Moreover, The Comecon showed a serious hegemonic tendency in the stage of the "gold dollar" system and could even arbitrarily change the trade terms with other countries in Stalin period.[10] The Soviet Union also made monetary integration attempts in accordance with the Bretton Woods System. The Transfer Rouble was the universal currency of the internal exchange of the Comecon, but could not be directly used for production or as an international currency like dollar. The Soviet Union, as the legal changer of the Transfer Rouble, controlled economic and trade exchanges of each country, and made each country lack of horizontal exchanges. The currency function of Transfer Rouble therefore suffered a great limit, mainly as follows: Economic and trade transactions could only be transferred by the rouble settlement, and could only be used to buy goods on the market of other countries, so that the transfer of rouble was more similar to a material media.[11] In short, the Transfer Rouble was not an international currency, did not have the currency function, severely restricted the development of the Transfer Rouble, and was known as "a stillborn infant."[12] The loss of the functions of the Transfer Rouble limited the development of the development of the Comecon from the monetary level and made it a really closed market. From this perspective, the Transfer Rouble putted an end to the possibility that the Bretton Woods System penetrated the Comecon by the currency, and enhanced the control of the Soviet Union on the Comecon and the Eastern European countries. From the perspective of the currency functions of the Transfer Rouble, the Comecon was only an international organization composed of a number of bilateral trade organizations, rather than the European Union's multilateral trade organization. The purpose of the Transfer Rouble was to consolidate the planned economic system, and maintain the normal operation of internal economic and trade exchanges of the Comecon. [13]

\section{CONCLUSION}

The Bretton Woods System and the Comecon represented two directions of the development of the regional financial system, and eventually evolved into the interaction between the two camps. The United States and the Soviet Union constructed the Bretton Woods and the Comecon, but at the same time the two systems also constructed the US- 
Soviet relations. The two systems constructed the national identity and institutional attributes of the United States and the Soviet Union. The opposing and independent system structure further defined the space and behavior of the foreign policy of the two countries, so that the two countries considered their own behavior, model function of the leader of respective system and chain reaction caused in order to protect the peace of the two countries and even two camps for decades.

\section{ACKNOWLEDGMENT}

This thesis is supported by the Zhejiang Philosophy and Social Science Program (18NDJC224YB).

\section{REFERENCES}

[1] Paul r. Krugman, Moutes Obersfarde, International Economics: Theory and Policy, Beijing: China Renmin University Press, 2011, str. 479-594.

[2] Henry Kissinger, Big Diplomacy, Beijing: People's Publishing House, 2010, 406.

[3] Hu Xiaofeng, Postwar American Economy, History Teaching. 10 (1997) 16.

[4] Tao Jikan, Postwar US economic growth rate and its prospects, World Economy, 5 (1979) 1.

[5] Hu Xiaofeng, Postwar American Economy, History Teaching. 10 (1997) 17.

[6] Prente Ge Kaiyi, Darrell Whitman, post-war international financial system evolution of the three stages and the global economic crisis, Foreign Theoretical Trends, 1 (2011)15.

[7] Fang Lianqing, Wang Bingyuan, Liu Jin quality editor, International Relations History (Post-war volume) Rudin, Beijing: Peking University Press, p.75.

[8] Fang Lianqing, Wang Bingyuan, Liu Jin quality editor, International Relations History (Post-war volume) Rudin, Beijing: Peking University Press, p.93.

[9] Li Xing, On the issue of the Comecon and the relationship between the Soviet Union and Eastern Europe, World History, 6 (1997) 18.

[10] Robert Conquist, The Last Empire - The Problem of Nationalities and the Future of the Soviet Union, Shanghai: East China Normal University Press, 1993, 367.

[11] Li Xing, On the issue of the Comecon and the relationship between the Soviet Union and Eastern Europe, World History, 6 (1997) 19.

[12] Liu Baorong, Soviet Eastern European countries gradually adjusted their respective economic and trade development strategy, The Problem of Soviet Union and Eastern Europe, 5 (1988) 62.

[13] Lu Chuanmin, The Revival of Eastern Europe and the Fate of the Comecon, World Economy and Politics, 6(1990) 62. 